\title{
EFFECTIVENESS OF THE VARIOUS MECHANISMS AND PRACTICES IN PREVENTING AND RESOLVING INDIVIDUAL LABOUR CONFLICTS IN ROMANIA
}

\author{
Lecturer Alexandra Braica PhD \\ "Vasile Goldis" Western University \\ E-mail: alexandra.braica@gmail.com \\ Serghei Mesaros \\ Ministry of Labour, Family, Social Protection and Elderly
}

(Received February 2015; accepted April 2015)

\begin{abstract}
In our country, the practice of individual labour dispute resolution shows that it predominantly appeals to the courts, to the detriment of alternative mechanisms for individual labour dispute prevention and resolution. Therefore, we believe the focus should be on developing those practices and mechanisms, on the one hand to prevent the emergence of a labour dispute, and on the other hand to steer the conflict settlement through mediation. This paper refers to the existing situation in Romania, in terms of legislation and practice in the field. Promoting programs to increase the institutional capacity of social partners for resolving labour disputes, both individual and collective, would be an approach in accordance with the principles of social dialogue and would really contribute to developing a culture of social dialogue in Romania.
\end{abstract}

Key Words: individual labour disputes, prevention, resolution, measures, legislation

\section{Introduction}

In Romania individual labour dispute resolution is governed by specific legislation (L.192/2006, L.53/2003). The Mediation of individual labour disputes falls under the general rules established by Law no. 192/2006 on mediation and the mediator profession (as amended). Mediation is optional and does not exclude recourse to the courts.

While economic factors are difficult to estimate, there are other elements we can focus to reduce the number of labour disputes. A key factor would be the development and promotion of information strategies on the rights and obligations provided by labour laws to reduce the number of labour disputes arising from them. In this respect, a primary role lies with the Labour Inspectorate, which should give priority to promoting such educational programs in the plan of activities that it currently runs. A very important role is played by trade union organisations that are authorised by law to assist their members in their relation with employers, in order to identify solutions for resolving disputes. 
From a legal standpoint, we believe it would be effective to revise the Law on mediation (L.192/2006 on mediation and the mediator profession, as amended) with regard to the reintroduction of mandatory information on the advantages of mediation, preliminary to any court actions. Thus, we believe that carrying out campaigns to promote mediation, supported by examples of good practice in labour dispute resolution, can raise the degree of alternative resolution of individual labour disputes.

The study of conflict management is increasingly addressed in human resources management, as it contributes to a better understanding of individual and group behaviour in the organisational sphere. In general, conflict appears as a form of human interaction in which two or more members of a group partly or fully disagree on some issues.

The term (A.P. Braica, 2009) of dispute covers all forms of intolerance, and results from attempts of incompatible influence between individuals and within groups and organisations. It is used to describe conflict situations, emotional states of individuals (hostility, frustration, agitation, restlessness or anxiety), cognitive states (awareness of conflict situations), or behavioural states (from passive resistance to upfront aggression).

As long as the parties manage to resolve their disputes directly and constructively, no intervention is required from other actors. When the dispute has reached a major impasse (for example it is extremely passionate, fiery, and communication is blocked), the intervention of third parties often remains the only solution. Third parties may contribute to resolving disputes through techniques such as reducing tension, controlling the number of problems, improving communication, establishing common topics or emphasising certain decision options to make them more attractive to parties. From our point of view, such interventions should be avoided as long as the parties manage to do without help, within reasonable limits of time and resources.

\section{Research Methodology}

In this paper we used bibliographical sources in the field and references to specific legislation.

The methodology used during the research was conceptualisation, identification of management elements applicable in conflict situations from the perspective of the central public administration at the institutional level where the conflict breaks out, with the necessary adaptation thereof. The research undertaken had a determining and experimental-formative character. Analysis - as a tool for applied research was performed through statements and statistics made at central government level, according to government data. Good results were yielded by the use models, the 
study of official documents or legislation governing this area in Romania, European norms, and documents issued by various institutions, subject to transparency. Data and information gained through the application of research instruments were processed using software applications.

I combined the theory reflecting, in a generalised form, the ideas, objectives, elements, concepts, principles defining the area of conflict management, the methodology approaching the methods, procedures of knowledge, research of the field, as well as specific action, managerial technology - which expresses, in essence, knowing how to do a concrete action rationally, efficiently, using theory and methodology, and practice - adapting above-mentioned elements to actual conditions.

The research required the study of specialised literature - economic, legal, sociological, psycho-sociological and pedagogical - which approached the issue of staff or human resources management, conflict management, labour law, as show in bibliographic references, with a direct impact in tackling the content pursued in the paper.

The research work consisted of: documentation, the study of organisational culture, the study of legal and practical aspects on labour legislation, mediation, statistic data processing and interpretation methods.

The involvement of the Social Dialogue Department within the Ministry of Labour, Family, Social Protection and Elderly, where I have been working for over two years, in such projects is opportune for conducting a program to develop alternative labour dispute resolutions, in order to decrease their negative effects.

\section{Results and discussion}

The settlement of individual labour disputes is regulated by the Labour Code (Law no.53/2003 republished in the Official Gazette of Romania, Part I, 345 of 18 May 2011) and the Law No. 62/2011 of Social Dialogue (as amended).

Law no.53/2003 (Labour Code) governs labour jurisdiction, defining the object, parties and powers of the courts (Art. 1, Art. 266, Art. 267, Art. 268, Art. 269). Therefore, the Labour Code (L.53/2003, as republished) governs labour relations, how to control the enforcement of regulations in the field of employment, as well as labour jurisdiction. Labour jurisdiction is aimed at resolving labour disputes concerning the conclusion, amendment, suspension and termination of individual or, where applicable, collective employment contracts, as well as claims relating to legal relations between social partners.

The following may be parties in labour disputes: 
a) employees and any other person holding a right or obligation under the Labour Code (L.53/2003, republished), other laws or collective employment contracts;

b) employers - individuals and/or legal persons, temporary employment agencies, users and other persons who benefit from work carried out under legal conditions;

c) trade unions and employers' organisations;

d) other natural or legal persons who have this vocation under special laws or the Code of Civil Procedure.

Claims to resolve a labour dispute can be submitted:

a) within 30 calendar days from the date on which the unilateral decision of the employer regarding the conclusion, amendment, suspension or termination of the individual employment contract was notified;

b) within 30 calendar days from the date of notification of the disciplinary measure;

c) within 3 years after the right of action becomes effective, if the object of the individual labour dispute is the payment of outstanding wages or damages to the employee, and in case of the employees' patrimonial liability to the employer;

d) throughout the duration of the contract, if the establishment of the nullity of an individual or collective employment contract, or clauses thereof, is requested;

e) within 6 months after the right of action become effective, in case of failure to execute a collective employment contract or clauses thereof.

In other situations, other than those listed above, the term is 3 years from the date when the right becomes effective.

Judging labour disputes is in the competence of courts established by law. Claims on the causes listed above are filed to the competent court having jurisdiction over the claimant's domicile or residence or, where appropriate, office. If the conditions laid down in the Code of Civil Procedure for active procedural co-participation are met, the claim may be filed submitted to the competent court for any of the claimants.

The Labour Code (L.53/2003, republished) also contains special procedural rules (According to Art. 266, Art. 270, Art. 271, Art. 272, Art. 273, Art. 274). Thus, labour jurisdiction is aimed at resolving labour disputes concerning the conclusion, performance, amendment, suspension and termination of individual or, where appropriate, collective employment contracts provided by the Labour Code (L. $53 / 2003$, republished), as well as claims regarding legal relations between social partners, established under the law. The cases provided above are exempt from judicial stamp duty and judiciary stamp.

Claims referring to the resolution of labour conflicts are judged urgently, and hearing dates cannot be set for more than 15 days. The summons procedure shall be deemed to have been duly accomplished if it takes at least 24 hours before the 
hearing date. It is important to note that the burden of proof in labour disputes falls on the employer, who is obliged to submit the evidence in his defence until the first day of hearings. It is legally held that the administration of evidence is subject to the regime of emergency, and the court is entitled to remove the benefit of admitted proof from the party who unduly delays its administration. The sentences pronounced by the court on the merits of the case shall be final and enforceable by law.

A special law governing the resolution of individual labour disputes is, in addition to the ones mentioned here, and the Law on Social Dialogue 62/2011 (as amended). The law specifies the competence of the courts, the types of rights that are the object of labour dispute and the related procedures (L. 62/2011, republished, Art. 208, Art. 210, Art. 211, Art. 212, Art. 213, Art. 214, Art. 215, Art. 216).

This normative act regulates here (L. 62/2011 on Social Dialogue) that individual labour disputes are resolved in the court of first instance. Claims relating to the resolution of individual labour disputes go to the court in whose jurisdiction the claimant resides or works. Such claims may be made by those whose rights have been violated, as follows:

a) unilateral measures for execution, amendment, suspension or termination of the individual employment contract, including commitments to pay certain sums of money, may be appealed within 45 calendar days of the date on which the party concerned became aware of the measure taken;

b) the nullity of an individual employment contract may be requested by the parties throughout the contract period to which that contract applies;

c) the payment of compensation for damage caused and the refund of amounts which formed the subject of undue payments may be requested within three years from the date when the damage occurred.

Likewise, the claims relating to the settlement of individual labour disputes shall be settled expeditiously, and the hearing dates cannot be set for longer than 10 days. The parties are legally summoned if the summons has been served with at least 5 days before judgement. First-instance decisions are only subject to appeal. The deadline for appeal is 10 days from the date of notification of the decision.

The provisions of the Law on Social Dialogue (L.62/2011) regarding the procedure for resolving individual labour disputes properly complement the Code of Civil Procedure (Law no. 214/2013 approving Government Emergency Ordinance no. 4/2013 amending the Law no. 76/2012 for the implementation of Law no. 134/2010 on the Code of Civil Procedure, and amending and supplementing certain related acts, published in the Official Gazette no. 388 of 28 June 2013).

1. Institutions involved in resolving individual labour disputes 
a) Judicial authorities

In Romania the competent institutions in individual labour dispute resolution are: the High Court of Cassation and Justice, through the United Sections of own competence; the Court of Appeal, through the Labour Dispute and Social Insurance Sections; the Court of first instance, through Labour Dispute and Social Insurance Sections; the Constitutional Court of Romania.

Although Law no. 304/2004 on judicial organisation (republished) expressly provides for the establishment of labour courts, to date, for budgetary and administrative reasons, such courts have not been established, which negatively influences the efficiency and speed in solving individual labour disputes.

The Constitutional Court has jurisdiction on individual labour disputes based on art. 41 of the Romanian Constitution (1991, amended in 2003) which states that:

The right to work cannot be restricted, and the choice of profession, trade or occupation, as well as place of work, is essentially free for every Romanian citizen. Employees are entitled to social security measures, targeting employee health and safety, the employment of women and young people, the establishment of a minimum gross salary per economy, weekly rest, paid annual leave, work under special conditions, training, and other specific conditions established by law. The normal working day is also regulated averaging to no more than 8 hours, according to international regulations. The Fundamental Law refers directly to gender equality, regulating equal pay for equal work, between women and men.

b) Conciliation or mediation, including administrative conciliation

The mediation of individual labour disputes is subject to the general regulations established by Law no. 192/2006 (as amended and supplemented) on mediation; the mediation of individual labour disputes is subject to the restriction stipulated by Article 38 of the Labour Code (L.53/2003), "Employees cannot waive the rights recognised to them by law. Any transaction that seeks waiver of rights recognised by law to employees or limitation of such rights is void."

Although these restrictions significantly reduce the possibility of mediation in labour disputes, there is a possibility mentioned in the national legal doctrine to apply mediation to various types of cases, such as:

$\checkmark$ disputes concerning rights individually negotiated by employees (other than those conferred by law);

$\checkmark$ disputes concerning the interpretation of ambiguous clauses in an individual employment contract;

$\checkmark$ disputes regarding the payment of compensation to cover damages;

$\checkmark$ disputes related to the establishment of invalidity of some clauses in the individual employment contract. 
Likewise, the national legislation provides the possibility of individual labour dispute mediation to pursue matters of discrimination, assigned to the National Council for Combating Discrimination (NCCD).

The mediation of individual labour disputes is carried out under Law no. 192/2006 (amended and supplemented) by authorised mediators. Mediation is optional and does not exclude recourse to the courts.

Third-party intervention may be required by the parties or be imposed from outside by rules, laws, customs set in an organisation etc. A third party can bring the perspective of someone who is not a party to the dispute, but who is interested in resolving the conflict.

Among the major benefits brought by the intervention of third parties are restoring stability and normalcy and engaging the parties in a civilised discourse in which negotiations to resolve the conflict can be restarted.

Other advantages can also be mentioned:

- creating a breathing space or a period to temperate passionate states;

- restoring or improving communication;

- focusing on important issues;

- remedying blocked relations;

- restoring commitments on deadlines;

- increasing the level of satisfaction and commitment of the parties to the dispute resolution process and its results.

Third-party interventions may be described as formal or informal. Formal interventions are recognised as traditional and are designed to play this formal role; they are used by judges and mediators of labour relations, whereas informal interventions occur incidentally to solve a conflict state.

Mediation is the most common form of intervention of third parties, and is mostly procedural in nature. During mediation, the parties retain control of the results, although they cede control over the settlement of the dispute. Mediation thus helps to keep an important benefit of negotiation: the parties retain control over solutions, which will help them significantly in their desire to implement the results.

Such an intervention (which insists on procedures) supports the needs of negotiators who seek guidance or procedural assistance, but want to keep control over decisions and the implementation of results. It should not be overlooked that the failure of third parties to use intervention (when really necessary), can be as dangerous as the wrong choice of interventions.

c) Arbitration

National legislation does not provide for arbitration of individual labour disputes.

d) Specialised institutions covering specific areas of individual labour disputes 
The National Council for Combating Discrimination (established by Government Decision no.1194 / 2001 on the organisation and functioning of the NCCD, as subsequently amended) is the autonomous state authority under parliamentary control, which operates in the field of discrimination. This is the guarantor of respect and enforcer of the principle of non-discrimination, in accordance with national legislation and international and EU agreements to which Romania is a party.

Tasks of the National Council for Combating Discrimination include mediation of acts of discrimination, including labour disputes related to employment and profession.

Thus, for example, the National Council for Combating Discrimination was notified in 2011 (Annual Report of the National Council for Combating Discrimination 2011) on a total of 28 disputes on grounds of discrimination in access to employment and professions.

On the other hand, the Ombudsman Institute (regulated by the Constitution, Chapter 4, art. 58-60) is an autonomous public authority, independent from any other public authority, and aims to safeguard the rights and freedoms of individuals in their relations with public authorities. Ombudsman (L.35/1997 on the organisation and functioning of the Ombudsman) is involved in the resolution of individual labour conflicts in relations with public authorities, and is empowered, in this regard, to require the public administration authorities concerned to end the violation of rights, to restore the rights and repair damage. The Ombudsman may refer the administrative court under the law.

In this area, in 2013 (Report of the Ombudsman for 2013), this institution reviewed a total of 280 claims. Among the claims resolved without opening a file, in labour relations, the following issues have been reported: failure to pay the salaries of employees of companies; the practice of some employers to put pressure on employees to terminate the employment contract by resignation or by agreement of the parties; the conduct of individual or collective dismissals; the failure to give appropriate legal holidays; exceeding the legal working hours without compensations payable by employers; failure to enforce a judgment which established the reinstatement of the claimant in the public service from which he was released and the payment of wages from which he would have benefited; possible delays from public institutions related to the payment of amounts provided in enforcement orders, granting salary rights to public sector staff; challenging the decisions of local agencies for employment (AJOFM- County Employment Agency) ordering the termination of unemployment benefits and debt recovery created; challenging dismissal decisions and ordering the employer to pay damages 
equal to wages indexed, increased and updated, and the other rights which the employee would have received in the situation prior to the act of dismissal.

e) Other procedures and processes

Under the Law on Social dialogue (L.62/2011, as amended), the trade unions have the right to assist members in their claim, in case of an individual labour dispute with the employer. The trade unions have locus standi to represent the legal interests of their members.

Thus, the Law No.62/2011 on Social Dialogue provides that trade unions have the right to use specific means such as negotiations, procedures to resolve litigation through conciliation, mediation, arbitration, petition, picketing, marching, rally and demonstration or strike (Art. 27). Trade unions also defend the rights of their members before courts, jurisdictional bodies, or other institutions and authorities, so they have locus standi (Art. 28)

\section{Other administrative authorities:}

The Labour Inspectorate (founded under L.108 / 1999 for the establishment and organisation of the Labour Inspectorate) performs the function of state authority, which exercises control in the areas of labour relations, occupational health and safety and market surveillance (GD no. 767/1999 for the approval of the Internal Regulation of the Labour Inspectorate).

The Labour Inspectorate acts to provide the social protection of labour, according to Art. 41 of the Constitution (amended by the Law amending the Constitution of Romania no. 429/2003, approved by national referendum on 18-19 October 2003 and entered into force on 23 October 2003), republished, the ILO Convention no. $81 / 1947$ on labour inspection in industry and commerce (ratified by Romania through the State Council Decree 284/1973), and he ILO Convention no. 129/1969 on Labour Inspection in Agriculture (ratified by Romania through the State Council Decree no. 83/1975).

The Labour Inspectorate (Article 1 of L. no. 108/1999 and Article 1 of GD no. 767/1999) has the following tasks in the field of labour relations:

a) to supervise the enforcement of legal regulations, both general and special, on the conclusion, performance, amendment, suspension and termination of individual employment contracts;

b) to control the establishment and granting of rights to the employees arising from the law, the applicable collective employment contract and individual employment contracts;

c) to monitor the implementation of measures to secure equal opportunities and equal treatment between women and men; 
d) to provide a record of the work done based on individual employment contracts at national level, through the general register of employees, as well as track day labourers and the beneficiaries of their work;

e) to supervise the use of workforce in order to identify cases of undeclared work;

f) to send and receive electronically, through local labour inspectorates, the data submitted by employers and beneficiaries related to employees and day labourers;

g) to ensure the registration of collective labour contracts at the unit level and check their provisions, according the procedure approved by the General State Inspector, and to reconcile labour disputes occurring in units.

In the area of prevention, the Labour Inspectorate is required to provide information to employers and employees on the enforcement of legal provisions in the areas of competence, in order to avoid labour disputes arising from ignorance of the law.

\section{Performance of mechanisms and procedures for resolving individual labour disputes}

By far, currently the most widely used mechanism for resolving individual labour disputes is the lawsuit. In this respect, the National Institute of Statistics (Statistic Bulletin - INS 2014) reflects the following situation:

\begin{tabular}{|l|l|c|}
\hline \multicolumn{1}{|c|}{ Item } & Year & Number of claims in court \\
\hline 1. & 2000 & 28,051 \\
\hline 2. & 2001 & 27,159 \\
\hline 3. & 2002 & 37,722 \\
\hline 4. & 2003 & 34,432 \\
\hline 5. & 2004 & 34,123 \\
\hline 6. & 2005 & 36,723 \\
\hline 7. & 2006 & 45,734 \\
\hline 8. & 2007 & 52,679 \\
\hline 9. & 2008 & 88,104 \\
\hline 10. & 2009 & 69,314 \\
\hline 11. & 2010 & 101,709 \\
\hline 12. & 2011 & 79,711 \\
\hline 13. & 2012 & 79,160 \\
\hline 14. & 2013 & 64,576 \\
\hline
\end{tabular}

It is worth noting that, in national judicial practice, the majority of labour disputes in court are won by employees. To a large extent this is due to procedural defects 
from employers who do not know and do not follow the correct procedure for sanctioning employees, as well as to employee-friendly legislative provisions (e.g. in labour disputes the burden of proof is reversed, the employer is obliged to prove the correctness of administrative measures adopted).

A second way of resolving individual labour disputes, in terms of frequency, is filing a claim to the local or national Labour Inspectorate. Note that the Labour Inspectorate may often defuse a conflict situation by administrative means.

In this regard, following checks carried out upon notification by employees claiming infringement of rights, the Labour Inspectorate orders measures to remedy the situation, possibly in conjunction with sanctioning employers for offenses, going up to the notification of prosecution bodies for cases stipulated by specific legislation in force. In exceptional circumstances, the Labour Inspectorate may request deletion of legal entities from the Trade Register (closing the unit).

Below is a situation (Report of the Labour Inspectorate for 2014) of potential labour disputes investigated by the Labour Inspectorate upon notification by employees:

\begin{tabular}{|l|c|c|}
\hline Item & Year & Number of claims \\
\hline 1. & 2006 & 38,989 \\
\hline 2. & 2007 & 44,974 \\
\hline 3. & 2008 & 57,195 \\
\hline 4. & 2009 & 69,527 \\
\hline 5. & 2010 & 65,833 \\
\hline 6. & 2011 & 60,665 \\
\hline 7. & 2012 & 69,324 \\
\hline 8. & 2013 & 65,733 \\
\hline
\end{tabular}

Please note that not all cases notified find resolution through administrative channels, an unidentifiable part of these complaints following the path of courts. However, we believe that the Labour Inspectorate plays the most important role in preventing individual labour disputes, through mechanisms informing the Parties on the legislative provisions concerning their rights and obligations. Also, we consider that often individual labour disputes are largely generated precisely by ignorance of such provisions.

Other mechanisms for resolving individual labour conflicts include, in order of their addressability, resolution by the Ombudsman, exemplifying the situation of 2013, when some 280 complaints were reviewed in the field of labour relations (Ombudsman Report for 2013). 
Labour disputes (employment and profession), generated on grounds of discrimination have been resolved by the National Council for Combating Discrimination (NCCD's Annual Report for 2011) in a total of 28 disputes in 2011. Although the NCCD is authorised by law to engage in mediation in reported court cases, in practice, this task is hardly exercised.

We find that the most common approach to individual labour dispute resolution is to go to court, given the guarantee provided by law, the full restoration of the injured employee in the context of an employee-friendly practice of the courts, also favoured by the exemption from court fees for labour disputes.

Labour Inspectorate interventions have a very high success rate in preventing and resolving individual labour disputes in view of high confidence in state authority and in virtue of the institution's legal empowerment to apply drastic measures to restore legality and decision-making power in such cases.

Calling on the National Council for Combating Discrimination or the Ombudsman Institution for intervention or counselling to resolve disputes in labour relations is infrequently used and has an irrelevant share in resolving such disputes.

\section{Complementarity/interaction between different institutions, mechanisms and processes}

We may mention the crucial interaction between the activities of the Labour Inspectorate and the courts. In this sense, we state that if, following the intervention of the Labour Inspectorate in an individual labour dispute, the statement of facts and the measures proposed by the Labour Inspectorate to remedy the situation are not implemented, they will become definitive evidence in case of a trial in court.

As regards other institutions and mechanisms, we find very little in the interconnection of their individual labour dispute resolution processes.

\section{Cooperation with Labour Inspectorates for better resolution of individual labour disputes}

Labour Inspectorate work is divided into two types of interventions: interventions in punctual referrals; campaigns conducted by the Labour Inspectorate, according to the work plan or geographical areas.

If in regard to punctual referrals, the situation is outlined above, they also have the role of preventing potential conflict situations through early identification and implementing a plan of action to eliminate the risks. The plan of action applied to prevent and eliminate risks is monitored.

Likewise, by analysing the incidence of risk factors for any individual labour disputes by unit types, industries or geographic areas (construction industry, trade, etc.), the Labour Inspectorate can optimise its own control plan. 
Trends and developments in individual labour disputes influencing individual labour dispute prevention and resolution mechanisms

The analysis of statistical data we have (INS Statistic Bulletin 2014 - with 2013 data) leads to the following assessments:

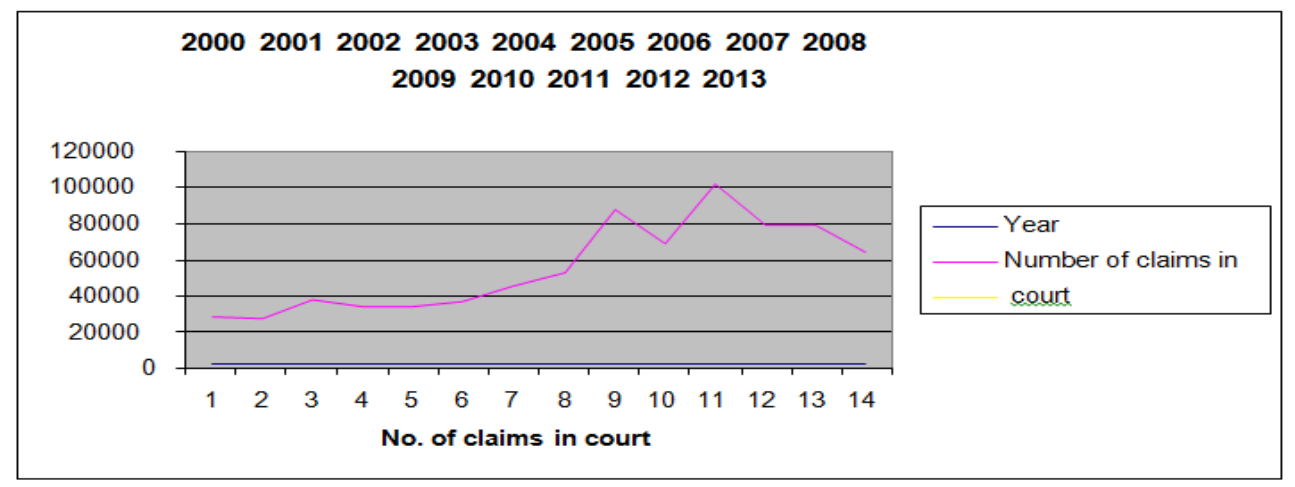

We find an increasing trend of individual labour disputes with two distinct peaks in 2008 and 2010. While in 2008 the increase in individual labour disputes was due to restructuring measures taken by employers as a result of the onset of the economic crisis (usually layoffs and wage cuts), which were challenged by employees in court, the 2010 increase is a consequence of the impact of legislative action to reduce wages in the budgetary sector, affecting over a million employees, many of them addressing the courts to challenge those measures.

Since the effects of the global crisis are still being felt in Romania, the measures taken by employers to reduce the effects of the crisis by restructuring jobs and cutting wage continues to generate a large number of individual labour disputes. It is difficult to predict, at this time, the dynamics of individual labour disputes, as the economic situation is not yet stabilised, although efforts are being made to this effect by the government.

\section{Other associated factors that positively or negatively influence individual labour dispute resolution}

We believe that one of the effective solutions for individual labour disputes remains mediation with the assistance of an authorised mediator, although there are conditions for using mediation in resolving individual labour disputes, in accordance with art. 38 of the Labour Code (L. 53/2003 republished, as amended). 
There is a wide range of types of cases in individual labour disputes which may be subject to mediation. Although this possibility exists, it is very little used, largely due to ignorance of those interested in these opportunities and benefits. To promote mediation as an alternative dispute resolution tool, including individual labour disputes, in 2012 there was a legislative amendment (GEO no. 90/2012 amending and supplementing L. 192/2006 on mediation and the mediator profession, as well as amending Article II of L. 115/2012 amending and supplementing L. 192/2006 on mediation and the mediator profession) in the Law on mediation (L. 192/2006) which obliges the parties to call on a mediator for information on mediation and its advantages before taking any court action. The information was provided free of charge.

The intention of the legislator was to relieve the courts of those trials that the parties could settle amicably. Surprisingly, with the entry into force of the new Code of Civil Procedure, this provision regarding the obligation to provide information on mediation was repealed.

Therefore in the absence of an officially supported mechanism to promote mediation, effective alternative resolution of individual labour disputes is very low, given the lack of a prolonged experience and tradition in this regard.

\section{CONCLUSIONS}

The practice of individual labour dispute resolution shows a prevalence of appeal to the courts, to the detriment of alternative individual labour dispute and prevention and resolution. As such, we believe the focus should be on developing those practices and mechanisms, on the one hand to prevent the emergence of a labour dispute, on the other hand to steer the conflict settlement through mediation. While economic factors are difficult to estimate, there are other elements that we should focus on to reduce the number of labour disputes. One such factor would be the development and promotion of information strategies on the rights and obligations provided by labour laws, to reduce the number of labour disputes arising from them.

In this sense, a key role goes to the Labour Inspectorate (centrally or locally), which should give priority to promoting such educational programs in the plan of action that it currently runs.

An important role is also played by trade unions, which are entitled, by law, to and assist its members in dealing with employers in order to identify solutions to resolve disputes.

In this respect, it is possible to support the trade unions in the training and specialisation of their representatives, in order to increase the capacity to mediate such conflicts. To support this approach, MMFPSPV (Ministry of Labour, Family, 
Social Protection and Elderly) has initiated a series of programs to increase the institutional capacity of social partners to solve labour conflicts, both individual and collective.

We believe that such an approach is consistent with the principles of social dialogue and contributes to the development of a social dialogue culture.

From a legal standpoint, we believe it would be effective to revise the Law on mediation (L. 192/2006) with regard to the reintroduction of mandatory information on the advantages of mediation, preliminary to any court actions. Independent of any such legislative changes, we believe that the conduct of campaigns to promote mediation, supported by examples of good practice in labour dispute resolution, can increase the degree of alternative resolution for individual labour disputes.

\section{REFERENCES}

1. A.P.Braica, Managementul resurselor umane, Editura "Vasile Goldis" University Press, Arad, 2009

2. V.Lefter, A.Manolescu, C.V.Marinas, A.Deaconu, Managementul resurselor umane, Editura ProUniversitaria, Bucuresti, 2012

3. A.Mayo, Valoarea umana a organizatiilor, BMI Publishing, 2014

4. O.Nicolescu, I.Verboncu, M.Profiroiu, Starea de sanatate a managementului din Romania in 2011 - analiza SWOT si recomandari fundamentate pe baza chestionarii a peste 2100 de specialisti, Editura Pro Universitaria, Bucuresti, 2012 5. I.Strainescu, Ben-Oni Ardelean, Managementul conflictelor, Editura Didactica si Pedagogica, Bucuresti, 2009

6. A.Ticlea, L.Georgescu, Dreptul securitatii sociale. Curs universitar - Editia a IV-a, Editura Universul Juridic, Bucuresti, 2013

7. A.Ticlea, Tratat de Dreptul Muncii, Editura Universul juridic, Bucuresti, 2014 8. The Romanian Constitution amended by the Law revising the Constitution no. 429/2003, published in Official Gazette of Romania, Part I, no. 758 of 29 October 2003, republished by the Legislative Council, pursuant to art. 152 of the Constitution, by updating the denominations and renumbering texts (art. 152 became, as republished, art. 156). The Law revising the Constitution no. 429/2003 was approved by national referendum on 18-19 October 2003 and entered into force on 29 October 2003, following publication in the Official Gazette of Romania, Part I, no. 758 of 29 October 2003, of the Constitutional Court Decision no. 3 of 22 October 2003 to confirm the result of the national referendum of 18-19 October 2003 on the Law revising the Romanian Constitution

9. Law no. 53/2003, republished in the Official Gazette of Romania, Part I, no. 345 of 18 May 2011, as amended and supplemented 
10. Law no. 62/2011 on social dialogue, republished in the Official Gazette of Romania, Part I, no. 625 of 31 August 2012

11. Law no. 214/2013 approving Government Emergency Ordinance no. 4/2013 amending the Law no. 76/2012 for the implementation of Law no. 134/2010 on the Code of Civil Procedure, and amending and supplementing certain related acts, published in the Official Gazette no. 388 of June 28, 2013

12. GD no. 1194/2001 on the organisation and functioning of the National Council for Combating Discrimination, as amended and supplemented

13. Law no. 35/1997 on the organisation and functioning of the Ombudsman

14. Law no. 304/2004, republished in the Official Gazette of Romania, Part I, no. 827 of 13 September 2005

15. Law no. 192/2006 on mediation and the mediator profession, amended and supplemented

16. Government Emergency Ordinance no. 90/2012 amending and supplementing Law no. 192/2006 on mediation and the mediator profession, and amending art. II of Law no. 115/2012 amending and supplementing Law no. 192/2006 on mediation and the mediator profession

17. Law no.108/1999 on the establishment and organisation of the Labour Inspectorate

18. GD no. 767/1999 for approval of the Internal Regulation of the Labour Inspectorate

19. GEO no. 86/2014 establishing reorganising measures in central public administration and amending and supplementing certain acts

20. ILO Convention no. 81/1947 on labour inspection in industry and commerce, ratified by the State Council Decree no. 284/1973,

21. ILO Convention no. 129/1969 on labour inspection in agriculture, ratified by the State Council Decree no. 83/1975

22. Report of the Ombudsman for 2013;

23. Annual Report of the National Council for Combating Discrimination for 2011;

24. Labour Inspectorate Report for 2014;

25. Statistical Bulletin - National Institute of Statistics in 2014 (with data from 2013); 